\title{
Flocculation onset, growth phase, and genealogical age in Saccharomyces cerevisiae
}

\author{
Eduardo V. Soares and Manuel Mota
}

\begin{abstract}
Flocculation onset, the time during the fermentative cycle at which the strains of Saccharomyces cerevisiae become flocculent, is an important factor in the brewing industry. The flocculation ability of Flol phenotype (strain NCYC 869) remained practically unchanged throughout the growth and seems to be insensitive to the presence of nutrients of the culture medium. On the contrary, the flocculation of NewFlo phenotype (strain NCYC 1195) exhibited a cyclic behaviour. It was found that the loss of flocculation in the early growth was the result of two combined effects: the dismantling of the flocculation mechanism of the cells coming from the inoculum and the nonflocculent state of the new cells produced after growth has started. The onset of flocculation of strain NCYC 1195 in the cultural conditions used in this work coincided with the end of the exponential grow'th, when the minimum glucose level in the culture medium was attained. It was demonstrated that it is possible to manipulate the flocculation onset by changing the initial glucose concentration in the culture medium.
\end{abstract}

Key words: yeast, flocculation inhibition, glucose limitation, flocculation onset, genealogical age.

\begin{abstract}
Résumé : Le seuil de flocculation, soit le moment où. durant le cycle de fermentation, les souches de Saccharomyces cerevesiae commencent à flocculer, est un paramètre important dans l'industrie du brassage de la bière. La capacité de flocculation du phénoty'pe Flol (souche NCYC 869) demeure pratiquement intacte au cours de la croissance et ne semble pas influencée par les éléments nutritifs présents dans le milieu de culture. Par contre, chez le phénotype NewFlo (souche NCYC1195), la flocculation apparaît de façon clyclique. La perte de la capacité de flocculation en début de croissance semble due à deux effets combinés : l'altération du mécanisme de flocculation des cellules qui viendrait de l'inoculum et l'état de non-flocculation des nouvelles cellules produites après le démarrage de la croissance. Dans les conditions de culture utilisées dans le présent travail, le seuil de flocculation de la souche NCYC1 195 coïncide avec la fin de la phase exponentielle de croissance au moment où la concentration de glucose dans le milieu de culture atteint sont minimum. Il a été démontré qu il est possible de modifier le seuil de flocculation en changeant la concentration initiale du glucose dans le milieu de culture.
\end{abstract}

Mots clés : levure, inhibition de la flocculation, limitation en glucose, seuil de flocculation, âge généalogique.

[Traduit par la rédaction]

\section{Introduction}

Flocculation can be defined as an asexual aggregation (Johnson et al. 1988) of single yeast cells in clumps with subsequent fast sedimentation from the medium in which they were suspended (Stewart 1975). The ability of yeast cells to adhere and form flocs is exploited in fermentation processes such as brewing and wine making (Stewart and Russell 1981) and in the production of ethanol with high density cultures (Comberbach and Bu'Lock 1984).

According to the lectin-like theory, initially suggested by Eddy and Rudin (1958) and subsequently developed by Taylor and Orton (1978) and Miki et al. (1982a, 1982b), in flocculent bonds of Saccharomyces cerevisiae a specific lectin (on floc-

Received October 13, 1995. Revision received January 12. 1996. Accepted January 16, 1996.

E.V. Soares. Departamento de Engenharia Química. Instituto Superior de Engenharia do Porto, Rua de S. Tomé, 4200 Porto, Portugal.

M. Mota. ${ }^{1}$ Departamento de Engenharia Biológica, Universidade do Minho. Largo do Paço 4709 Braga Codex. Portugal.

1 Author to whom all correspondence should be addressed. culent cells) recognizes and interacts with carbohydrate residues of the $\alpha$-mannan (receptor) on the neighbouring cell walls, using calcium ions to ensure correct conformation of the lectins. Using mnn mutants and concanavalin A (ConA), it was shown that flocculation receptors are the outer-chain mannan side branches of two or three mannose residues in length (Stratford 1992). Two flocculation phenotypes (Flol and NewFlo) were distinguished according to their different sensitivity to sugar inhibition and protease sensitivity (Stratford and Assinder 1991). These two phenotypes have also different sensitivity to cultural conditions, namely to the $\mathrm{pH}$ of culture medium and growth temperature (Soares et al. 1994).

Flocculation of Saccharomyces cerevisiae is genetically controlled. Several FLO genes, their suppressors, and several mutations have been implicated in this phenomenon (Johnston and Reader 1983; Stratford 1994; Teunissen et al. 1995a, $1995 b$ ). Recently, the $F L O 1$ gene was cloned and its complete nucleotide sequence was determined (Teunissen et al. 1993; Watari et al. 1994). The FLOI gene product has been localized at yeast cell surface (Bidard et al. 1995) and might be anchored in the plasma membrane at the $\mathrm{C}$-terminal region by an integral membrane domain or a glycosylphosphatidylinositol (GPI) anchor (Teunissen et al. 1993; Watari et al. 1994; Bidard et al. 1995).

Can. J. Microbiol. 42: 539-547 (1996). Printed in Canada / Imprimé au Canada 
Besides the genetic factor, cultural (temperature and $\mathrm{pH}$ ) and nutritional conditions (nitrogen, carbon source and concentration) influence flocculation (Nishihara et al. 1976; Soares et al. 1991, 1994). Classically, flocculation has been described as an inducible property that in brewing strains (in the laboratory and in the brewery) was expressed towards the end of the exponential phase of growth (Stewart and Russell 1981). Strains that flocculate in all stages of growth are also described in the literature (Miki et al. 1982a, 1982b; Mota and Soares 1994); however, flocculation expression of some of these strains may be modulated, by changing growth temperature (Soares et al. 1994), or repressed under anaerobic conditions (Miki et al. 1982b; Soares et al. 1991).

Flocculation characteristics of a brewing yeast strain is of paramount importance to the brewer, namely the period during the fermentation cycle when the culture begins expressing flocculation (the onset of flocculation). A suitable strain for brewing purposes must be able to flocculate after growth and also ferment the sugars of the medium (wort) as discrete cells (Stewart and Russell 1981). Premature flocculation or failure of the yeast (although still in suspension) to utilize all of the fermentable wort sugars leads to an incomplete attenuation of the wort. On the other hand, later flocculence or failure of the strain to flocculate impairs the separation of the strain from the fermented wort and causes some difficulty in obtaining a bright sparkling beer (Stewart 1975). Moreover, the permanence of yeasts in suspension makes cell reuse difficult and off-flavors can often result owing to yeast autolysis (Stewart et al. 1976). Reasons for the onset of flocculation are poorly known; however, in lager brewer's yeast strains nitrogen (Smit et al. 1992) or oxygen limitations (Straver et al. 1993) have been described to trigger the flocculation.

In this work, the variation of flocculation ability with the growth phase of two strains representative of two different flocculation phenotypes was studied. A detailed study of the inhibition of flocculation of the NewFlo strain was performed. Additionally, the influence of glucose limitation on the onset of flocculation was also investigated.

\section{Materials and methods}

\section{Strains}

Two flocculent strains of Saccharomyces cerevisiae were used in this work. They were NCYC 1195 and NCYC 869 (FLOI). The first strain is a typical NewFlo phenotype strain and the second one is a typical Flol phenotype strain (Stratford and Assinder 1991). Two nonflocculent strains were also used: Schi=osaccharomyces pombe (ICV'M, Montpellier, France) and Saccharomyces sake (IAM, Tokyo); Saccharomyces sake, which is a recognized synonym for Saccharomyces cerevisiae (Bamett et al. 1983).

\section{Media and culture conditions}

Yeast strains were maintained at $4^{\circ} \mathrm{C}$ on yeast extract - peptone dextrose (YEPD) and agar slants, containing the following per litre of water: yeast extract (Difco), $10 \mathrm{~g}$; Bactopeptone (Difco), $20 \mathrm{~g}$; glucose (Merck), $20 \mathrm{~g}$; agar (Difco), $20 \mathrm{~g}$.

Precultures of flocculent strains were prepared in $40 \mathrm{~mL}$ of YEPD in 100-mL Erlenmeyer flasks. The cells were incubated at $30^{\circ} \mathrm{C}$ on an orbital shaker (Braun Certomat R) at $150 \mathrm{rpm}$. After $48 \mathrm{~h}$ of growth. flocculent cells were harvested by centrifugation $(4500 \times g .5 \mathrm{~min})$ and washed twice with $30 \mathrm{mM}$ EDTA solution to ensure floc dispersion. Finally, cells were washed and suspended in deionized water.
Experimental cultures of flocculent strains were inoculated with about $1 \times 10^{6}$ cells $/ \mathrm{mL}$ from precultures in $1.7 \mathrm{~L}$ of YEPD, in a $2-\mathrm{L}$ mechanically stirred $(250 \mathrm{rpm})$ Biolab fermentor (Braun, Melsungen, Germany). The cultures were constantly aerated with sterilized air at $10.2 \mathrm{~L} / \mathrm{h}$ and $30^{\circ} \mathrm{C}$. For studies regarding the effect of glucose concentration on the onset of flocculation and the study of loss of flocculation in the early growth, the cultures were inoculated with about $1 \times 10^{6} \mathrm{cells} / \mathrm{mL}$ from precultures in $1-\mathrm{L}$ Erlenmeyer flasks containing $0.4 \mathrm{~L}$ of YEPD. Unless stated otherwise, initial glucose concentration in the medium was $20 \mathrm{~g} / \mathrm{L}$. Cells were grown at $30^{\circ} \mathrm{C}$ on a orbital shaker at $150 \mathrm{rpm}$. In the case of the study of loss of flocculation, various flask cultures were inoculated at the same time and all culture of the flask was removed at a given time point.

Schizosaccharomyces pombe and Saccharomyces sake were precultured under the same conditions as the flocculent strains. Cultures were prepared by inoculating $0.4 \mathrm{~L}$ of YEPD in 1-L Erlenmeyer flasks in a preculture to fresh medium ratio of $1: 10$. Cells were grown at $30^{\circ} \mathrm{C}$ for $48 \mathrm{~h}$ on a orbital shaker at $150 \mathrm{rpm}$. After growth, yeasts were harvested by centrifugation $(4500 \times \mathrm{g}, 5 \mathrm{~min})$ and washed twice in $250 \mathrm{mM}$ EDTA solution. Subsequently, cells were washed twice and resuspended in deionized water.

\section{Experimental determinations with cultures of flocculent strains}

At the times indicated throughout growth, samples were taken from the cultures. For glucose determinations, aliquots were filtrated by acrodiscs of $0.45 \mu \mathrm{m}$ (Gelman). The filtrates were collected in Eppendorf tubes and immediately stored in the freezer until glucose determination (see below).

Except for the case of growth measurement (see below), cells from the samples were harvested by centrifugation $\left(4500 \times \mathrm{g}, 5 \mathrm{~min}, 4^{\circ} \mathrm{C}\right.$ ), washed twice, resuspended on ice-cold distilled water, and stored at $4^{\circ} \mathrm{C}$ for a maximum of $24 \mathrm{~h}$ for determination of genealogical age or $72 \mathrm{~h}$ for measurement of flocculation. Control experiments showed that with this procedure, yeasts kept the same flocculation ability and the same genealogical profile. Prior to the measurement of flocculation and competition experiments, cells were washed twice with $250 \mathrm{mM}$ EDTA solution, washed again twice, and resuspended in deionized water.

\section{Grouth measurement}

Growth was monitored spectrophotometrically (Hitachi U 1100) at $620 \mathrm{~nm}$ using a calibration curve as reference or by direct cell counting with a hemacytometer, after the appropriate dilution of the samples in $250 \mathrm{mM} \mathrm{NaCl}$ solution at $\mathrm{pH} 2.0$ to prevent cell aggregation.

\section{Glucose determination}

The glucose concentration in the culture medium was monitored by using glucose oxidase-peroxidase method (Boehringer Mannheim) in a Hitachi 750 analyzer, after removal of the cells from the samples by filtration as described above.

\section{Measurement of flocculation ability}

The flocculation ability of the strains NCYC 1195 and NCYC 869 was monitored using a microflocculation technique, similar to the technique described by Stratford and Assinder (1991).

Cell suspensions were placed in $50 \mathrm{mM}$ citrate buffer ( $\mathrm{pH} 4.5$ ) containing $4 \mathrm{mM} \mathrm{CaCl}_{2}$, in test tubes of $15 \mathrm{~mm}$ diameter and $50 \mathrm{~mm}$ of high. at a final concentration of $5 \times 10^{7} \mathrm{cells} / \mathrm{mL}$. The final volume of the suspension was $2.0 \mathrm{~mL}$. The tubes were sealed, stirred vigorously in a vortex for $10 \mathrm{~s}$. and agitated in a horizontal position during $4 \mathrm{~h}$ on a orbital shaker (Braun Biostat M) at $100 \mathrm{rpm}$. After agitation the tubes were allowed to stand undisturbed for $30 \mathrm{~s}$ in a vertical position, after which samples $(100-200 \mu \mathrm{L})$ were taken from just below the meniscus and dispersed in $250 \mathrm{mM} \mathrm{NaCl}$ solution at pH 2.0 . 
Fig. 1. Time course of growth, flocculation. and glucose utilization by strain NCYC 869.

Flocculent cells were inoculated in $1.7 \mathrm{~L}$ of YEPD with $20 \mathrm{~g} / \mathrm{L}$ of glucose as the carbon source. in a 2-L fermentor. For other experimental details, see Materials and methods. Each point represents the mean of three measurements. This is a typical example of an experiment repeated three times.

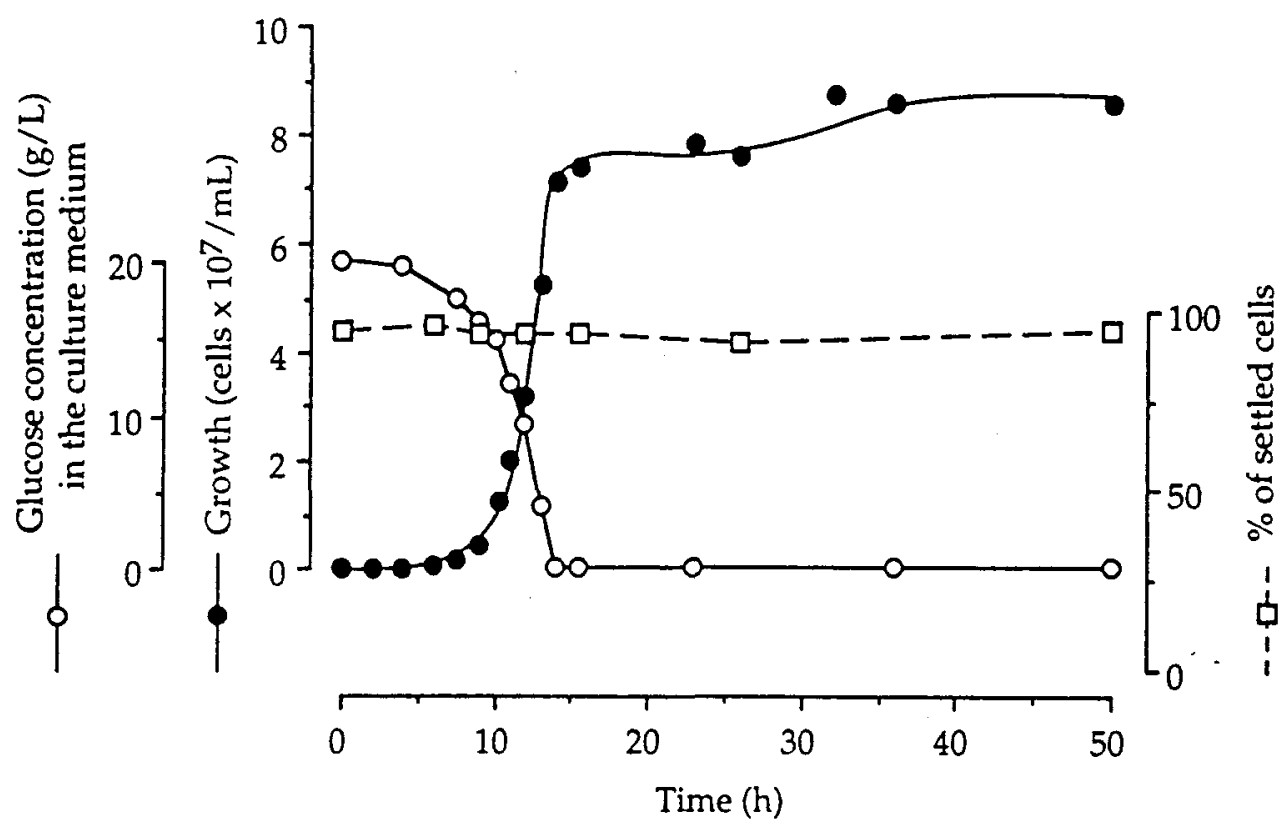

The cell concentration was determined spectrophotometrically at $620 \mathrm{~nm}$ using a calibration curve as reference.

Control experiments have shown that the results obtained with the microflocculation technique described above were comparable in a quantitative manner with the technique in 100 - $\mathrm{mL}$ flasks described by Stratford and Assinder (1991) (data not shown).

\section{Competition experiments}

The interaction ability between nonflocculent cells (either nonflocculent or not expressing flocculence) and flocculent cells (strain NCYC 1195, grown $48 \mathrm{~h}$ ) was tested in a $1: 1$ nonflocculentflocculent suspension, each at $3 \times 10^{7}$ cells $/ \mathrm{mL}$. The blends placed in the tubes described above were stirred vigorously for $10 \mathrm{~s}$ in a vortex. Flocculation was initiated by $\mathrm{CaCl}_{2}$ addition at a final concentration of $4 \mathrm{mM}$. The final volume was $2.0 \mathrm{~mL}$. The buffer and agitation conditions (time and speed) were the same as those used in the measurement of flocculation described above. After agitation, the cell concentration in the suspension was determined spectrophotometrically as described earlier. Control tubes, with flocculent and nonflocculent ceils, were made separately and similarly agitated and sampled. Using these data, the proportion of senled cells and nonflocculent cells integrated in the flocs were determined and expressed as percentages.

\section{Bud scar analysis}

Bud scar analysis was carried out on samples of cells taken at different times throughout growth of the strain NCYC 1195, after staining with fluorescent dye. Aliquots of cells suspensions were washed three times with $30 \mathrm{mM}$ EDTA solution and twice with deionized water. The cell pellets were resuspended and stained in $2 \mathrm{~mL}$ of $2 \mathrm{mg}$ Calcofluor $/ \mathrm{mL}$ (Sigma) for $10 \mathrm{~min}$ in the dark at room temperature. Cells suspensions were harvested by centrifugation $(4500 \times \mathrm{g}, 5 \mathrm{~min})$ and washed twice with an excess of deionized water. The cells were observed in a Zeiss Axioskop microscope, using incident ultraviolet light with appropriate filters (excitation filter. $365 \mathrm{~nm}$; dichroic mirror, $395 \mathrm{~nm}$; barrier filter, $420 \mathrm{~nm}$ ). The genealogical profile of samples taken during the growth was determined by scoring the number of bud scars.
To determine the parent cycle time (eq. 3 , see below), cells taken in the exponential phase of grow'th $(11 \mathrm{~h})$ were also assigned to one of the following classes: (i) unbudded daughters; (ii) budded daughters; (iii) unbudded parents with $n$ scars; and (iv) budded parents with $n$ scars, where $n$ took a value $\geq 1$. With these data, the fraction of budded cells and the fraction of budding parent cells were calculated.

For each sample about 1000 cells were scored. The fluorescence observed at the isthmus of a budded cell was not scored as a scar.

\section{Theoretical distribution of bud scars}

Theoretical genealogical age distribution in exponential phase of growth was calculated using the following Lord and Wheals (1980) equations:

$$
\begin{aligned}
& \text { [1] } \quad F_{\mathrm{D}}=\mathrm{e}^{-\alpha P} \\
& \text { [2] } \quad F_{\mathrm{P}_{n}}=\left(\mathrm{e}^{-\alpha P}\right)^{n-1}\left(1-\mathrm{e}^{-\alpha P}\right)^{2}
\end{aligned}
$$

where $F_{\mathrm{D}}$ is the fraction of daughter cells (age $\left.n=0\right), F_{\mathrm{P}_{n}}$ is the fraction of parent cells with $n$ scars $(n=1,2,3$, etc.), and $\alpha=\ln (2 / \tau) . P$ is the parent cycle time, which can be calculated using the following equation (Lord and Wheals 1980):

$$
P=\frac{\ln \left[\left(F_{\mathrm{B}} / F_{\mathrm{PB}}\right)+1\right]}{\ln 2} \times \tau
$$

where $F_{\mathrm{B}}$ is the fraction of budded cells, $F_{\mathrm{PB}}$ the fraction of parent cells that are budding, and $\tau$ is the daubling time (in minutes). $F_{\mathrm{B}}$ and $F_{\mathrm{PB}}$ were determined as described above.

\section{Results}

The two strains showed different behaviour in the relationship between growth phase and flocculation. The strain NCYC 869 flocculated during all phases of growth (Fig. 1). The flocculation ability of this strain seems to be insensitive to the presence 
Fig. 2. Time course of growth, flocculation, and glucose utilization by strain NCYC 1195 .

Flocculent cells were inoculated in $1.7 \mathrm{~L}$ of YEPD with $20 \mathrm{~g} / \mathrm{L}$ of glucose as the carbon source, in a 2-L fermentor. For other experimental details, see Materials and methods. Each point represents the mean of three measurements. This is a typical example of an experiment repeated three times.

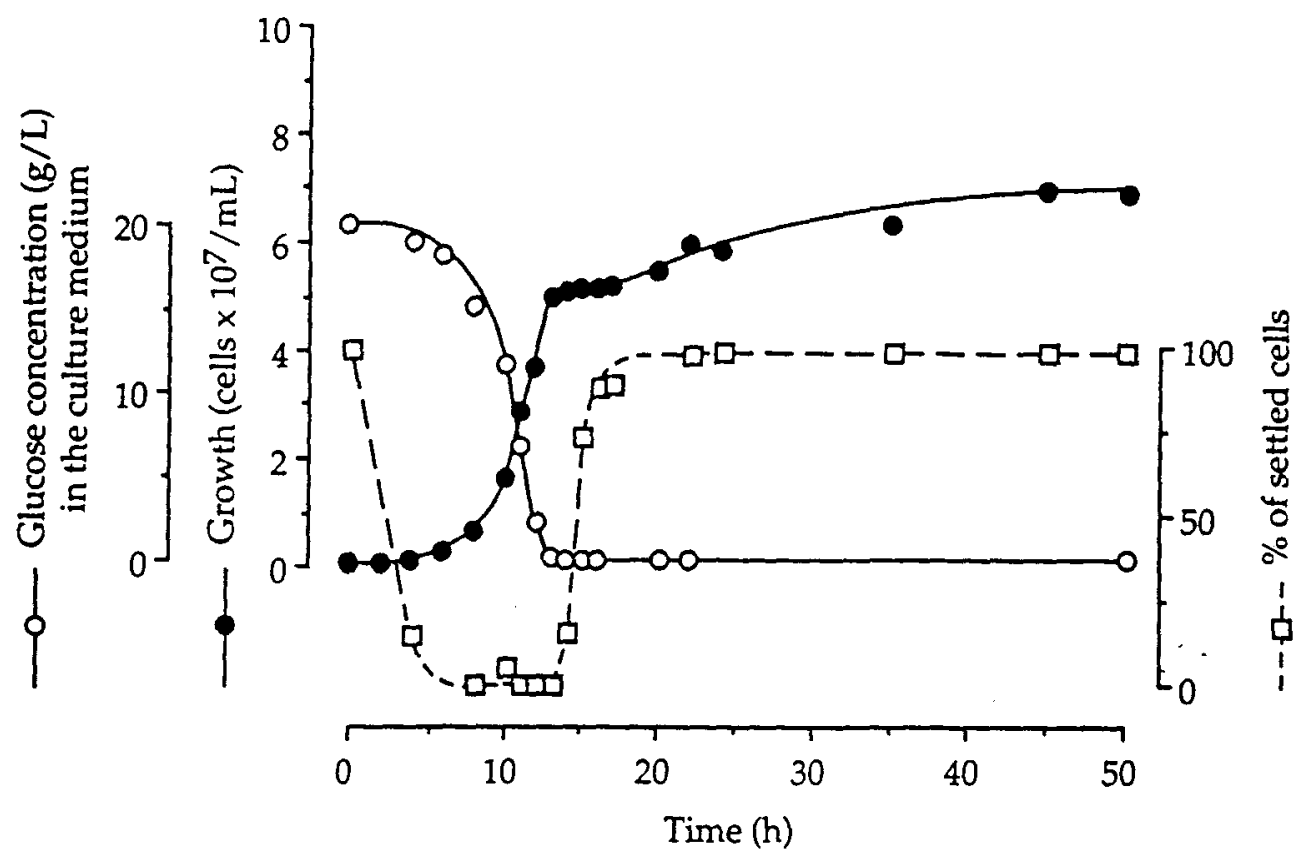

Fig. 3. Declining of flocculation of strain NCYC 1195. Flocculent cells were inoculated in $0.4 \mathrm{~L}$ of YEPD with $20 \mathrm{~g} / \mathrm{L}$ of glucose as the carbon source, in 1-L Erlenmeyer flasks. At the times indicated in the figure, cells were collected and $5 \times$ $10^{7}$ cells $/ \mathrm{mL}$ was placed in citrate buffer $(50 \mathrm{mM}, \mathrm{pH} 4.5)$ containing $\mathrm{CaCl}_{2}$ ( $4 \mathrm{mM}$ ). Cell suspensions were agitated during $4 \mathrm{~h}$ on a orbital shaker at $100 \mathrm{rpm}$. For more experimental details, see Materials and methods. Each point represents the mean of two measurements. This kind of experiment was performed twice with similar results.

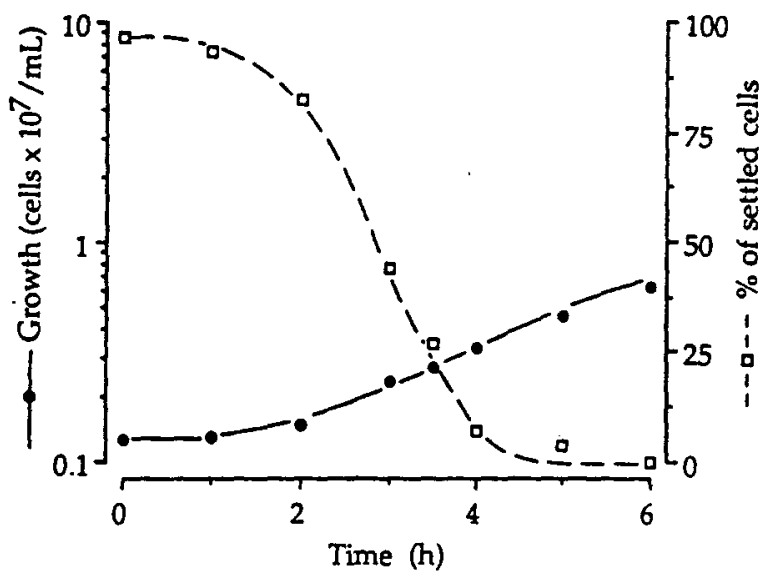

of nutrients in the culture medium, namely glucose, in the culture conditions used. On the contrary, in the case of the strain NCYC 1195, it was possible to distinguish three phases (Fig. 2). The first phase corresponded to the lag phase and to the beginning of the exponential phase of growth. As can be seen from the fraction of settled cells, highly flocculent cells coming from the inoculum, when transferred to fresh medium. were induced to growth and the strain progressively lost its ability to interact and form flocs. In the second phase, the strain grew exponentially, as single cells, with a doubling time of around $120 \mathrm{~min}$. The beginning of the third phase corresponded to the end of the exponential phase of growth (about $13 \mathrm{~h}$ ). The determination of glucose concentration and the flocculation ability of the cells showed that the depletion of the carbon source (glucose) from the medium was concomitant with the triggering of flocculation (Fig. 2). Budding cells could be detected at this phase of growth. Macroscopically, the onset of flocculation in the culture medium was detected after $16-17 \mathrm{~h}$ and the culture was highly flocculent at $20 \mathrm{~h}$.

A more detailed study shows that the gradual loss of flocculation of strain NCYC 1195 begins when the cells are in lag phase (Fig. 3). However, a dramatic fall of flocculation occurred after $2 \mathrm{~h}$, in the beginning of exponential phase; after $3-4 \mathrm{~h}$ of growth, the total number of cells was nearly twice of the inoculum. These results raise two hypotheses: $(i)$ the new daughter cells are nonflocculent and the abrupt loss of flocculation may be attributed to the gradual dilution of the inoculated flocculent cells or (ii) there is also a dismantling of the flocculation mechanism previously exhibited by the inoculated cells. To elucidate this point it was, therefore, decided to investigate the role of the genealogical age on the flocculation of strain NCYC 1195.

The genealogical age of the cells was determined by bud scar analysis. Table 1 shows the distribution of the genealogical age of the cell population in different phases of growth. As can be seen, the profile of the genealogical age throughout the growth was essentially identical. In all phases of growth, there were 
Table 1. Relationship between genealogical age and the different phases of growth of the strain NCYC 1195.

\begin{tabular}{ccccccc}
\hline & \multicolumn{7}{c}{ \% cells at the following genealogical ages ${ }^{a}$} \\
\cline { 2 - 7 } Time (h) & 0 & 1 & 2 & 3 & 4 & $>4$ \\
\hline 0 & 52.1 & 27.1 & 14.1 & 3.96 & 1.98 & 0.79 \\
8 & 43.9 & 37.2 & 10.6 & 6.40 & 1.60 & 0.30 \\
11 & 49.5 & 25.1 & 12.3 & 7.43 & 3.66 & 1.98 \\
14 & 52.0 & 26.0 & 15.4 & 3.90 & 1.08 & 1.52 \\
22 & 43.9 & 29.6 & 14.2 & 8.75 & 1.39 & 2.19 \\
50 & 53.8 & 27.4 & 12.3 & 3.89 & 2.37 & 0.19 \\
\hline
\end{tabular}

Note: A Chi-square value of 3.03 was determined for $t=11 \mathrm{~h}$. The theoretical \% cells for each genealogical age was calculated from [1] and [2] and $P=102 \mathrm{~min}$ (for more details, see Material and methods). The critical $\chi^{2}$ for 0.05 level of significance ( 5 degrees of freedom) was 11.07 .

${ }^{a}$ Genealogical a:se $(n)$ is equal to the number of bud scars. About 1000 cells were scored for each time of growth. The results were taken from the samples of the experiment shown in Fig. 2

$43.9-53.8 \%$ daughter cells. Therefore, the flocculation ability of the daughter cells (cells that never budded) is an important factor on the establishment of the flocculent characteristics of the whole culture. As a control, the experimental distribution of the genealogical age of the culture in exponential phase of growth $(t=11 \mathrm{~h})$ was compared with the theoretical values based on $P=102 \mathrm{~min}$ and [1] and [2]. The two distributions (experimental and theoretical) were compared using the Chisquare test (Miller and Miller 1984). There was no difference between the two distributions for a 0.05 level of significance (Table 1).

Since during the budding period the assembling of the newly synthesized glucan and mannoprotein is predominantly confined to the growing bud (Tkacz and Lampen 1972; Cabib et al. 1982), the cell wall of the growing bud was practically de novo synthesized, keeping very little material from the parental cell wall (Cabib et al. 1982). This fact raises the possibility that the zero-age daughter cells do not possess the flocculation components in their cell walls (i.e., flocculation lectins and (or) carbohydrate receptors), as it was suggested by Bielecki and Brzeski (1989), contributing to the dramatical loss of flocculation observed when the growth starts (Fig. 3).

To test whether the daughter cells are nonflocculent and therefore correlating with the loss of flocculation, competition experiments were performed using flocculent and nonflocculent cells in a ratio $1: 1$; this ratio was used because in all phases of growth there was nearly $50 \%$ daughter cells. If the daughter cells were nonflocculent, two different situations could be considered: the daughter cells were nonflocculent, because there was neither flocculation lectins nor receptors, or the daughter cells were nonflocculent, because they had no lectins for flocculation, but they had receptors in active conformation for flocculation lectins.

It is known that owing to the composition and structure of the cell wall of Schizosaccharomyces pombe, these cells are unable to be aggregated by flocculent cells of Saccharomyces cererisiae in competition experiments (Miki et al. 1982a). Cells of Schizosaccharomyces pombe were, therefore, used as a model of nonflocculent cells without receptors, compatible with the flocculation lectins of Saccharomyces cererisiae. In a previous work, it was shown that the cells of the nonflocculent strain Saccharomyces sake have receptors in active conformation for flocculation lectins (Soares et al. 1992). These cells were used as a model of nonflocculent cells with receptors. Cells of strain NCYC 1195 in a nonflocculent period (exponential phase of growth) were also used. In all the competition experiments reported above, NCYC 1195 cells with 2 days of grow'th were used as flocculent cells.

As may be seen in Fig. 3, at $4 \mathrm{~h}$ of growth there was $50 \%$ daughter cells and only $10 \%$ flocculation. If all the daughters were nonflocculent and all the parent cells remained flocculent, $80 \%$ flocculation would have been expected, as in competition experiments shown in Fig. 4. Therefore, this shows that the floçculation mechanism is being dismantled.

The loss of flocculation ability of strain NCYC 1195 can be due, in a general mode, to a loss, blockade, or inactivation of the lectins for flocculation or the receptors. The presence and availability of the receptors for flocculation in a phase of growth in which the strain was unable to form flocs was evaluated using competition experiments. Nonflocculent cells of strain NCYC 1195 (during the exponential phase of growth) were able to interact with flocculent cells of the same strain being integrated in the flocs (Fig. 4). The percentage of nonflocculent cells of strain NCYC 1195 integrated in the floc: (about 60\%) was found to be constant throughout exponentia. growth (data not shown).

Furthermore, since in Fig. 2 it was observed that there was a recovery in flocculence coincident with the glucose depletion. it was necessary to prove whether there was a casual link between the glucose level and the flocculation onset. Therefore, three further experiments with different glucose levels were designed to confirm the previous results.

As can be observed in Fig. 5, the triggering of flocculation of strain NCYC 1195 when grown in YEPD coincided with the end of the exponential phase of growth and with the depletion of carbon source (glucose) in the culture medium. By this way, it is possible to manipulate the flocculation onset by changing the initial concentration of glucose in the culture medium.

\section{Discussion}

\section{The loss of flocculation}

The NewFlo phenotype (strain NCYC 1195) showed a progressive loss of flocculation when first cultured. remaining nonflocculent during all exponential phase of growth (Fig. 2). 
Fig. 4. Competition experiments. Flocculent cells of Saccharomyces (Sacch.) cerevisiae NCYC 1195 were mixed with three different types of nonflocculent cells: cells with receptors for flocculation (represented by Saccharomyces (Sacch.) sake), cells without receptors (represented by Schizosaccharomyces (Schiz.) pombe), and strain NCYC 1195 in exponential phase of growth. Cells were mixed at $1: 1$ ratio, each at $3 \times 10^{7}$ cells $/ \mathrm{mL}$. Buffer, calcium concentration, and agitation (time and speed) were the same as those described in Fig. 3. Each bar represents the mean of three measurements. This is a typical example of an experiment repeated three times.

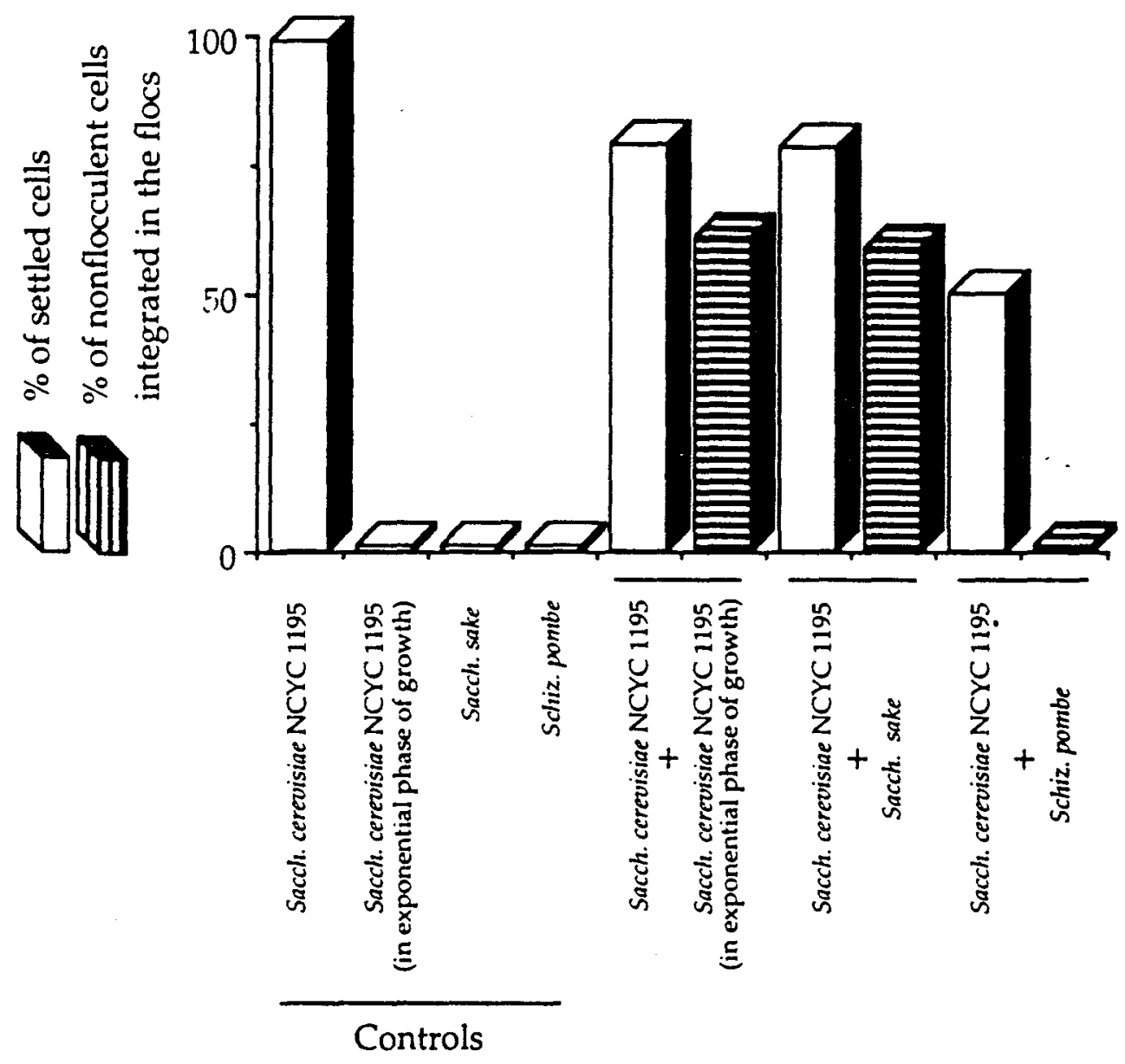

In the early stage of growth, the flocculent cells coming from the inoculum were gradually diluted as a consequence of boming of new cells (daughter cells). As the cells coming from the inoculum corresponds to $50 \%$ of the whole population, after 3-4 h of growth (Fig. 3), if these cells retained their flocculation ability, the minimum of settled cells should be $50 \%$, as was demonstrated in the competition experiments (Fig. 4). The results obtained were clearly different (Fig. 3), which suggest that probably, the abrupt loss of flocculation observed after $2 \mathrm{~h}$ of growth was a consequence of two combined effects: the dismantling of the flocculent mechanism of the cells coming from the inoculum and the nonflocculent state of the daughter cells. The dismantling of the flocculent mechanism is compatible with the continuous changing composition and architecture of the cell wall of batch-grown cells and with the cell wall composition and assembly dependence on the external conditions, such as nutrient availability, reported in the literature (Klis 1994).

However, it is important to note that the flocculation capacity of the cells with genealogical age zero should not be different from the parent cells. That is, the whole population (daughter and parent cells) should have the same flocculation ability: all are flocculent or nonflocculent. The whole cell population is homogeneous with respect to flocculation ability. When flocculation is expressed, the daughter cells must have receptors for flocculation lectins; otherwise, the maximum of settled cells should be $50 \%$, as in the case of $50 \%$ suspension of Schizosaccharomyces pombe (Fig. 4). On the other hand, the daughter cells must also have flocculation lectins; otherwise, the maximum ability of the population to flocculate would be $80 \%$ (Fig. 4), as is the case of a suspension with $50 \%$ nonflocculent cells with receptors (cells of Saccharomyces sake). This percentage of settled cells is clearly different from the behaviour observed when the flocculation is expressed. In this situation more than $95 \%$ of cells settle (Fig. 2). The observation of flocs stained with Calcofluor suggests, as in the case of Schizosaccharomyces pombe flocculation (Calleja 1987), that the flocs seem to be a result of a random assortment of generations.

The flocculation competence of yeast cells was tested all along with growth under standard conditions. Consequently, 
the loss of flocculation ability of strain NCYC 1195 during growth was most likely due to a modification in the composition or structure of the yeast cell wall. The competition experiments performed in this work using nonflocculent cells of strain

- NCYC 1195 (in exponential phase) and flocculent cells of the same strain (with 2 days of growth) showed that these nonflocculent cells had the ability to interact with flocculent cells and were integrated in the flocs (Fig. 4). This means that nonflocculent cells have receptors for flocculation lectins in a correct conformation. Curiously, the percentages of nonflocculent cells of strain NCYC 1195 aggregated in the competition experiments were similar to that obtained with the nonflocculent strain of Saccharomyces sake, which is a strain known to have receptors for flocculation lectins (Soares et al. 1992).

The exclusion of the cells of Schizosaccharomyces pombe from the flocs is a significant finding because it proves that the nonflocculent cells of NCYC 1195 (in exponential phase of growth) and Saccharomyces sake were not accidentally trapped inside the floc matrix. The aggregation of these nonflocculent cells was due to the interaction with flocculent cells and the formation of a true flocculation binding. The results presented above are in agreement with those obtained by Stratford (1993) and suggest that the loss of flocculation ability of strain NCYC 1195 in the exponential phase was probably due to the absence of the lectin-like component. This possibility is supported by observations that the lectin-like component of strain NCYC 1195 cannot be visualized (using neoglycoproteins fluorescent probes) in exponential phase (Masy et al. 1992).

\section{Glucose limitation and the onset of flocculation}

The flocculation of the brewer's ale yeast strain NCYC 1195 was triggered when the end of the exponential phase of growth was reached, which coincided with the minimum level of carbon source (Fig. 2). The stoppage of exponential cellular proliferation was due to glucose depletion. This possibility was supported by glucose determination in culture medium, which is in agreement with the data available in the literature. According to these reports, glucose was the limiting factor when yeast strains were grown in YEPD, since addition of glucose to YEPD culture allows additional growth (Lillie and Pringle 1980). At this time of growth budding, cells can be observed that are typical of a diauxic growth shown by the most strains of Saccharomyces cerevisiae (Lewis et al. 1993). By changing the initial concentration of glucose in the culture medium, the time of the onset of flocculation was modified. In all situations, flocculation was triggered after glucose depletion in the culture medium (Fig. 5), which clearly shows a casual link between glucose depletion and the induction of flocculation of strain NCYC 1195 in YEPD.

According to Teunissen et al. (1995a), the flocculation genes are regulated at the transcriptional level. Since the disruption of TUPI gene leads to the relief of catabolite repression (Gancedo 1992) and the appearance of flocculence (Lipke and Hull-Pillsbury 1984), it was proposed that flocculation genes can be regulated by the proteic complex Ssn6-Tupl (Teunissen et al. 1993). Thus, after release of the catabolic repression, mediated by the general repressor of transcription Ssn6-Tup1 (Keleher et al. 1992), flocculation might be produced. The data presented in this paper support this hypothesis, since flocculation onset of the ale strain NCYC 1195 coincides with a low
Fig. 5. Relationship between growth, glucose limitation, and flocculation of strain NCYC 1195. Flocculent cells were inoculated in 1-L Erlenmeyer flasks containing $0.4 \mathrm{~L}$ of YEPD with different initial glucose concentrations: $\square, 10 \mathrm{~g} / \mathrm{L}$; $\Delta, 20 \mathrm{~g} / \mathrm{L} ; 0,30 \mathrm{~g} / \mathrm{L}$. For more experimental details, see Materials and methods. Each point represents the mean of three measurements. This is a typical example of an experiment repeated three times.
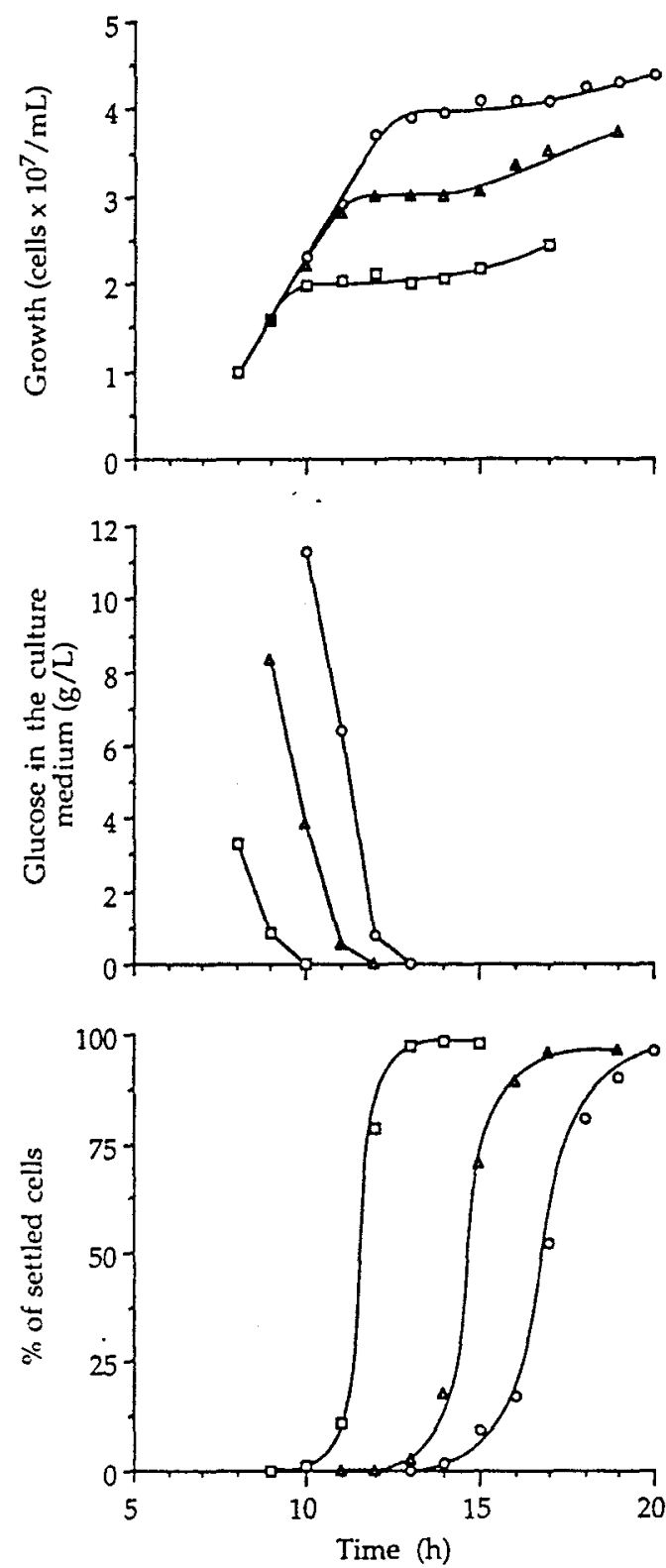

level of glucose. On the other hand, the results presented can be conciliated with those describing the need of glucose for flocculation expression (Mill 1964). As can be seen in Fig. 2. the flocculation was triggered when the glucose reached the minimum level; however, a residual concentration of glucose remained in the culture medium (about $0.020 \mathrm{~g} / \mathrm{L}$ ), which may be sufficient for flocculation expression. Our results are also in agreement with those of Teunissen et al. (1995a) who found 
that the peak of mRNA in a NewFlo strain precedes the flocculation onset.

The progressive recovery of flocculation ability of strain NCYC 1195 (Fig. 5) can be explained by the fact that, in the end of exponential phase, the physiological state of the whole population is a combination of the different situation of cells in the cell cycle and their genealogical age. Since parental cells have lower affinity for the substrate than daughter cells, the former respond earlier to the lower substrate concentration than the latter, by stopping cell growth (Vraná et al. 1982). This suggests that asynchronous stoppage of exponential cell proliferation can be the origin of the progressive recovery of flocculation ability. Probably, the parental cells were the first to stop exponential growth and to recover flocculation competence.

The results presented in this work show that Flol phenotype strain (NCYC 869) presented constitutive flocculence when grown in YEPD, flocculating in all phases of growth with the same intensity (Fig. 1). During the lag phase, the strain seemed unable to flocculate. However, this was due to the low cellular density of the culture medium. When these cells were harvested from the culture medium, adjusted to the standard cell density of the flocculation test, and allowed to settle in a buffer solution, they were highly flocculent (Fig. 1). Most likely, in this strain flocculation lectins are continuously synthesized. It is important to note that in the case of the Flol strain (NCYC 869), a possible modification on the composition or structure of the cell wall throughout the growth does not affect the flocculation ability of the cells.

In conclusion, the overall results presented in this work show that the flocculation ability of strain NCYC 869 (Flol phenotype) was not affected by the variation of the physiological state of the cells throughout the growth. On the other hand, strain NCYC 1195 (NewFlo phenotype) exhibited a cyclic flocculation; the strain progressively lost flocculation ability when inoculated in fresh YEPD medium (in the early period of growth) and recovered its flocculation competence after the end of exponential phase of growth, coinciding with the depletion of glucose in the culture medium. For this strain, a casual link between glucose depletion and the onset of flocculation was revealed.

\section{Acknowledgements}

The authors thank Dr. José M. Morais for his help in glucose determinations. This work was supported by Junta Nacional de Investigação Científica e Tecnológica (JNICT). E.V.S. was financially supported, during experimental work, by a grant from JNICT (BD/Bic/M/52/90-IF).

\section{References}

Bamett, J.A., Payne, R.W., and Yarrow, D. 1983. Yeasts: characteristics and identification. Cambridge University Press, Cambridge.

Bidard, F., Bony, M., Blondin, B., Dequin, S., and Barre, P. 1995. The Saccharomyces cerevisiae $F L O l$ flocculation gene encodes for a cell surface protein. Yeast, 11: 809-822.

Bielecki, S., and Brzeski, H. 1989. Characterization of non-flocculent cells isolated from a culture of flocculent Saccharomyces cererisiae NCYC 1001. FEMS Microbiol. Lett. 61: 189-194.

Cabib, E., Roberts, R., and Bowers, B. 1982. Synthesis of the yeast cell wall and its regulation. Annu. Rev. Biochem. 51: 763-793.
Calleja, G.B. 1987. Cell aggregation. In The yeasts. Vol. 2. Edited by A.H. Rose and J.S. Harrison. Academic Press Inc., London. pp. $165-238$.

Comberbach, D.M., and Bu'Lock, J.D. 1984. Continuous ethanol production on the gas lift tower fermentor. Biotechnol. Lett. 6: $129-134$.

Eddy, A.A., and Rudin, A.D. 1958. Part of the yeast surface apparently involved in flocculation. J. Inst. Brew. 64: 19-21.

Gancedo, J.M. 1992. Carbon catabolite repression in yeast. Review. Eur. J. Biochem. 206: 297-313.

Johnson, B.F., Walker, T., Calleja, G.B., and Seligy, V.L. 1988. Sexual co-flocculation and asexual self-flocculation in budding and fission yeasts: experimental establishment of a fundamental difference. Can. J. Microbiol. 34: 1105-1107.

Johnston, J.R., and Reader, H.P. 1983. Genetic control of flocculation. In Yeast genetics, fundamental and applied aspects. Edited by J.F.T. Spencer, D.M. Spencer, and A.R.W. Smith. SpringerVerlag, New York. pp. 205-224.

Keleher, C.A., Redd, M. J., Schultz, J., Carlson, M., and Johnson, A.D. 1992. Ssn6-Tup1 is a general repressor of transcription in yeast. Cell, 68: 709-719.

Klis, F.M. 1994. Review: cell wall assembly in yeast. Yeast, 10: 851-869.

Lewis, J.G., Northcott, J.C., Learmonth, R.P., Attfield, P.V., and Watson, K. 1993. The need for consistent nomenclature and assessment of growth phases in diauxic cultures of Saccharomyces cerevisiae. J. Gen. Microbiol. 139: 835-839.

Lillie, S.H., and Pringle, J.R. 1980. Reserve carbohydrate metabolism in Saccharomyces cerevisiae: response to nutrient limitation. J. Bacteriol. 143: 1384-1394.

Lipke, P.N., and Hull-Pillsbury, C. 1984. Flocculation of Saccharomyces cerevisiae tup I mutants. J. Bacteriol. 159: 797-799.

Lord, P.G., and Wheals, A.E. 1980. Asymmetrical division of Saccharomyces cererisiae. J. Bacteriol. 142: 808-818.

Masy, C.L., Henquinet, A., and Mestdagh, M. 1992. Fluorescence study of lectinlike receptors involved in the flocculation of the yeast Saccharomyces cerevisiae. Can. J. Microbiol. 38: 405-409.

Miki, B.L.A., Poon, N.H., James, A.P., and Seligy, V.L. $1982 a$. Possible mechanism for flocculation interactions governed by gene FLOI in Saccharomyces cerevisiae. J. Bacteriol. 150: 878-889.

Miki, B.L.A., Poon, N.H., and Seligy, V.L. 1982b. Repression and induction of flocculation interactions in Saccharomyces cerevisiae. J. Bacteriol. 150: 890-899.

Mill, P.J. 1964. The effect of nitrogenous substances on the time of flocculation of Saccharomyces cerevisiae. J. Gen. Microbiol. 35: 53-60.

Miller, J.C., and Miller, J.N. 1984. Statistics for analytical chemistry. Ellis Horwood Ltd. Publishers, John Wiley \& Sons Ltd., New York.

Mota, M., and Soares, E.V. 1994. Population dynamics of flocculating yeasts. FEMS Microbiol. Rev. 14: 45-51.

Nishihara, H., Toraya, T., and Fukui, S. 1976. Factors affecting flocculation of brewer's yeast. J. Ferment. Technol. 54: 351-355.

Smit, G., Straver, M.H., Lugtenberg, B.J.J., and Kijne, J.W. 1992. Flocculence of Saccharomyces cerevisiae cells is induced by nutrient limitation, with cell surface hydrophobicity as a major determinant. Appl. Environ. Microbiol. 58: 3709-3714.

Soares, E.V., Teixeira, J.A., and Mota, M. 1991. Influence of aeration and glucose concentration in the flocculation of Saccharomyces cerevisiae. Biotechnol. Lett. 13: 207-.212.

Soares, E.V., Teixeira, J.A., and Mota, M. 1992. Interaction between flocculent and nonflocculent cells of Saccharomyces cerevisiae. Can. J. Microbiol. 38: 969-974.

Soares, E.V., Teixeira, J.A., and Mota, M. 1994. Effect of cultural and nutritional conditions on the control of flocculation expression of Saccharomyces cerevisiae. Can. J. Microbiol. 40: 851-857.

Stewart, G.G. 1975. Yeast flocculation. Practical implications and experimental findings. Brew. Dig. 50: 42-62. 
Stewar, G.G., and Russell, I. 1981. Yeast flocculation. In Brewing science. Vol. 2. Edited by J.R.A. Pollock. Academic Press, London. pp. 61-92.

Stewar, G.G., Garrison, I.F., Goring, T.E., Meleg, M., Pipasts, P., and

- Russell, I. 1976. Biochemical and genetic studies on yeast flocculation. Kemia-Kemi, 10: 465-479.

Stratford, M. 1992. Yeast flocculation: receptor definition by $m n n$ mutants and concanavalin A. Yeast, 8: 635-645.

Stratford, M. 1993. Yeast flocculation: flocculation onset and receptor availability. Yeast, 9: 85-94.

Stratford, M. 1994. Genetic aspects of yeast flocculation: in particular, the role of FLO genes in the flocculation of Saccharomyces cerevisiae. Colloids Surf. B, 2: 151-158.

Stratford, M., and Assinder, S. 1991. Yeast flocculation: Fiol and NewFlo phenotypes and receptor structure. Yeast, 7: 559-574.

Straver, M.H., van der Aar, P.C., Smit, G., and Kijne, J.W. 1993. Determinants of flocculence of brewer's yeast during fermentation in wort. Yeast, 9:527-532.

Taylor, N.W., and Orton, W.L. 1978. Aromatic compounds and sugars in flocculation of Saccharomyces cerevisiae. J. Inst. Brew. 84: $113-114$.
Teunissen. A.W.R.H., Holub, E., van der Hucht, J., van den Berg, J.A and Steensma, H.Y. 1993. Sequence of the open reading frame $c$ the $F L O 1$ gene from Saccharomyces cerevisiae. Yeast, 9: 423-42:

Teunissen, A.W.R.H., van den Berg, J.A., and Steensma, H.Y 1995a. Transcriptional regulation of flocculation genes in $S a c$ charomyces cerevisiae. Yeast, 11: 435-446.

Teunissen, A.W.R.H., van den Berg, J.A., and Steensma, H.Y $1995 \mathrm{~b}$. Localization of the dominant flocculation genes FLO5 anc FLO8 of Saccharomyces cerevisiae. Yeast, 11: 735-745.

Tkacz, J.S., and Lampen, J.O. 1972. Wall replication in Saccharomy ces species: use of fluorescein concanavalin A to reveal the site 0 : mannan insertion. J. Gen. Microbiol. 72: 243-247.

Vraná, D., Votruba, J., and Placek, J. 1982. Age-related changes ir. the physiological state of budding yeast cells. Exp. Cell Res. 138: $57-62$.

Watari, J., Takata, Y., Ogaw'a, M., Sahara, H., Koshino, S., Onela, M. Airaksinen, U., Jaatinen, R., Penttilä, M., and Keränen, S., 1994. Molecular cloning and analysis of the yeast flocculation gene FLOl. Yeast, 11: 211-225. 